\title{
MRGPRX2 wt Allele
}

National Cancer Institute

\section{Source}

National Cancer Institute. MRGPRX2 wt Allele. NCI Thesaurus. Code C124963.

Human MRGPRX2 wild-type allele is located in the vicinity of 11p15.1 and is approximately $6 \mathrm{~kb}$ in length. This allele, which encodes Mas-related G-protein coupled receptor member X2 protein, is involved in both mast cell activation and receptor signaling. 